\title{
KONSUMERISME MASYARAKAT MODERN DALAM KAJIAN HERBERT MARCUSE
}

\author{
Rina Octaviana \\ Universitas Islam Negeri Sunan Gunung Djati Bandung \\ rinaoctavia99@gmail.com
}

\begin{abstract}
Abstrak
Perkembangan zaman yang semakin hari semakin berubah dan meluas hingga memberikan dampak yang sangat signifikan di kehidupan manusia. Dari berkembangnya zaman ini sudah pasti akan memberikan berbagai dampak baik itu negatif dan positif. Kritik mengenai zaman globalisasi ini salah satunya dilontarkan oleh seorang filsuf Jerman ternama dan juga seorang pemikir kiri baru yang bernama Herbert Marcuse. Perkembangan zaman yang membuat masyarakat saat ini berkiblat hanya pada satu dimensi saja yaitu kapitalisme. Kemudian dari kejadian ini lahirlah suatu budaya baru yang dinamakan budaya konsumerisme. Penelitian ini dilakukan untuk lebih mengetahui mengenai masyarakat modern dan juga berbagai bentuk konsumerisme masyarakat modern dalam kajian Herbert Marcuse. Kecanggihan dari teknologi dan kemajuan dari globalisasi memang sangat memberikan dampak baik bagi kehidupan manusia, namun tidak menafikan juga terdapat dampak buruk yang sangat besar yang dialami oleh manusia. Maka dari itu dengan lebih dibahasnya permasalahan mengenai masyarakat modern dan konsumerisme ini, maka diharapkan dapat digunakan sebagai bahan referensi agar masyarakat tidak terbuai dengan berbagai efek negative yang diberikan oleh arus globalisasi. Hasil penelitian ini kemudian menemukan bahwa perilaku masyarakat modern saat ini memang menjadi suatu perilaku yang sulit untuk dihindari. Dalam bukunya One Dimensional Man, Herbert Marcuse dengan gamblang mengatakan bahwa masyarakat modern saat ini merupakan masyarakat berdimensi satu yang telah berkiblat pada satu budaya yaitu budaya konsumerisme.
\end{abstract}

Kata kunci: masyarakat modern, konsumerisme, Herbert Marcuse, dan kapitalisme

\begin{abstract}
The development of the times is increasingly changing and expanding to have a very significant impact on human life. From the development of this era, it will definitely give various impacts both negative and positive. One of the critics about globalization is brought up by a famous German philosopher and also a new left thinker named Herbert Marcuse. The development of
\end{abstract}


the era that makes the current society is oriented to only one dimension, namely capitalism. Then from this incident was born a new culture called the culture of consumerism. This research was conducted to find out more about modern society and also various forms of consumerism in modern society in the study of Herbert Marcuse. The sophistication of technology and the progress of globalization is very good impact on human life, but it does not deny there are also very large adverse effects experienced by humans. Therefore, with more discussion about the problems of modern society and consumerism, it is expected to be used as a reference material so that people are not swayed by the various negative effects provided by the current of globalization. The results of this study later found that the behavior of modern society today is indeed a behavior that is difficult to avoid. In his book One Dimensional Man, Herbert Marcuse clearly says that today's modern society is a one-dimensional society that has been oriented to one culture, namely consumerism culture.

Keywords: modern society, consumerism, Herbert Marcuse, and capitalism

\section{A. Pendahuluan}

Sebagai suatu bentuk budaya yang terlahir di era milenial, budaya populer tentu tidak asing di telinga masyarakat. Budaya pop di era ini merupakan budaya dari suatu pengalaman yang terlahir karena budaya konsumsi dan di dukung oleh teknologi informasi yang serba baru. ${ }^{1}$ Jika kategori seni yang di ciptakan masyarakat akan bertahan di karenakan kehendak bangsa rakyat dengan tradisinya, seni yang bertemakan kerakyatan akan bertahan karena kehendak bangsa dengan ideologi kerakyatannya, maka seni populer terlahir bahkan mampu bertahan karena kehendak media dengan menggunakan ideologi kapitalisme dan konsumsi.

Kemunculan media dan konsumsi akan mengeser suatu ikatan sosial yang pada awalnya mementingkan aspek moral dan kognisi dan kemudian tergantikan oleh ikatan yang estetik. Perkembangan media saat ini seperti yang telah dialami sekarang menempatkan kita terhadap suatu hubungan antar manusia dan media menjadi semakin erat. Hal ini berdampak pada manusia

1 M.Psi Safuwan, "Gaya Hidup, Konsumerisme Dan Modernitas," Jurnal SUWA Universitas Malikussaleh V, no. 1 (2007): 38-46, http://repository.unimal.ac.id/1342/1/Gaya Hidup Modern.pdf. 
yang tidak bisa lagi menggunakan media sebagai fungsi dalam mengungkap suatu ide dari gagasan bahkan suatu perasaan manusia, namun saat ini medialah yang mengatur gagasan dan menata perasaan manusia.

Zigmunt Bauman telah melukiskan situasi ini sebagai awal dari menguatnya wilayah estetik dan memudarnya wilayah kognitif serta wilayah moral. Meminjam pendapat dari Martin Buber, ia menggambarkan telah terjadinya sebuah kesalahpahaman diantara manusia. Manusia tidak berdiri dengan sesama manusia sebagai neighbour melainkan berdiri sebagai stranger. Mereka tengah berada didalam suatu tempat yang sama tetapi tidak mengalami kepekaan terhadap sekitarnya. Mereka merasakan perasaan yang sama namun mengalami civic indifference (ketidakpedulian sipil). Untuk mengetahui kebenaran yang terjadi kepada massa konsumen media, memerlukan suatu penelitian yang empiris dan menyeluruh. Secara metodologis, kajian mengenai media telah mengembangkan berbagai cara untuk meneliti ke arah sana. Hasil dari temuan ini dapat meninjau kembali mengenai apa sebenarnya yang disebut populer dan dimana tempat yang seharusnya bagi budaya populer ini.

Di samping dari media, pengalaman budaya pop ini terkait dengan konsumsi. Media telah menciptakan sesuatu yang populer dengan cara mengosumsi barang-barang komoditi. Budaya pop yang alami pada era ini merupakan budaya pop yang terlahir dari cara orang-orang mengonsumsi barang-barang (mode of consumption). Sistem kebutuhan saat ini tidak lagi ditentukan oleh kebutuhan yang riil melainkan telah diatur dan diciptakan sesuai dengan keberadaan barang-barang komoditi. Sistem masyarakat dalam konsumsi cepat berubah mengikuti sistem kebutuhan dan sistem fungsi-fungsi. Sehingga ikatan sosial tidak hanya terbentuk atas dasar kebutuhan barang yang di konsumsi, tapi juga suatu keinginan dalam mengonsumsi barang tersebut. Intinya suatu konsumsi barang dan jasa bukan lagi bersifat kebutuhan 
melainkan keinginan dari setiap individu yang terhanyut kedalam dunia konsumtif yang diciptakan oleh media. ${ }^{2}$

Jadi dapat dilihat betapa rumit dan kuatnya kekuatan dari media dan konsumsi yang membentuk dan mengubah realitas rakyat dan kerakyatan menjadi realitas populer. Dimanakah suatu pengalaman rakyat dan kerakyatan yang sebelumnya? Pasti tidak akan tergantikan oleh realitas populer begitu saja. Akan tetapi, pada waktu yang sama akan dirasa terlalu naif bagi kita untuk kembali bernostalgia dengan realitas rakyat dan kerakyatan tanpa melewati realitas populer. Teori mengenai budaya pop diatas menunjukkan realitas populer telah ditentukan oleh komunikasi massa dan ada kemungkinan bagi kita untuk mempengaruhi kemajuan dari budaya populer tersebut baik itu bersifat negatif maupun yang bersifat positif. ${ }^{3}$

Teknologi selalu mempunyai suatu keunggulan tersendiri, di sisi ketakjuban terhadap teknologi selalu berderetan dengan kegelisahan yang ditimbulkannya. Ketika masyarakat telah menjadikan teknologi sebagai kiblatnya dalam kegiatan sehari-hari, hal tersebut sebenarnya memberikan efek kegelisahan.

Salah satu contohnya adalah dengan teknologi yang semakin aktual, maka akan terlahir darinya suatu budaya yang terbilang konsumtif di kalangan masyarakat. Kecanggihan teknologi yang tiada hentinya memang tengah menjadi suatu trending topic di kehidupan masyarakat, sehingga tidak ada satupun kegiatan manusia yang luput dari jasa teknologi. Berbagai macam kegiatan manusia yang dibantu dengan teknologi, maka akan ada suatu konsekuensi yang harus diterima oleh masyarakat salah satunya adalah dengan terlahirnya suatu "budaya baru" yang mulai berkembang pada saat ini. Salah satu permasalahan dari budaya baru tersebut yakni akan muncul budaya

\footnotetext{
${ }^{2}$ Herbert Marcuse, Manusia Satu Dimensi (Yogyakarta: Narasi. ${ }^{2016}$ ), hlm. 8

${ }^{3}$ Dominic Strinati, Popular Culture: Pengantar Menuju Teori Budaya Populer (Yogyakarta: Ar-Ruzz Media, 2010), hlm. 13-19
} 
konsumerisme yang diakibatkan oleh rangsangan dari berbagai macam komoditi yang dihasilkan oleh cyberspace.

Di Indonesia sendiri, konsep mengenai life style terlahir di era 1990-an. Gaya hidup tersebut lahir karena diakibatkan oleh adanya globalisasi di bidang industri media. Masyarakat Indonesia yang tergolong sebagai masyarakat konsumen di era tersebut lambat laun akan mulai tumbuh seiring pertumbuhan ekonomi global. Hal ini dapat ditandai dengan semakin menjamurnya pusat perbelanjaan, industri dibidang fashion, kecantikan, kuliner, gosip, dengan semakin disukainya produk asing, banyaknya makanan cepat saji, dan beberapa faktor lainnya yang merupakan efek dari life style yang diakibatkan dari iklan dan televisi.

Adapun hal yang digolongkan kedalam penyebab dari kemunculan budaya konsumer ini salah satunya adalah seorang public figure (selebritis). Seperti yang diungkapkan oleh Primada Qurrota Ayun, Adorno dan Max Horkheimer mengatakan bahwa tren dari gaya hidup para selebritis merupakan suatu gaya hidup yang dapat memudarkan kemanusiaan, karena dengan gaya hidup para selebritis yang cukup glamour dapat membuat massa terhipnotis untuk menirukan gaya hidup para selebritis. Selebritis sendiri merupakan suatu kelompok yang secara tidak sadar akan memicu adanya penindasan dalam segi ekonomi, hal tersebut akan menumbuhkan suatu khayalan-khayalan dan mimpi palsu bagi para penggemarnya. ${ }^{4}$

Dengan tren gaya hidup para selebritis maka akan meciptakan suatu identitas. Identitas itu sendiri adalah suatu deskripsi yang mencerminkan mengenai diri dari suatu subjek, sedangkan identitas sosial merupakan gambaran yang di berikan oleh orang lain mengenai hasil dari penilaian orang lain terhadap subjek tersebut. Sedangkan yang dimaksud dengan identitas

${ }^{4}$ Primada Qurrota Ayun, dkk, Cyberspace and Culture (Yogyakarta: Mata Padi Pressindo, 
sosial yaitu suatu pemaknaan yang definisinya ditampilkan melalui pemakaian dari beberapa tanda, khususnya pemakaian dari atribut-atribut badaniah.

Secara keseluruhan maka identitas sosial ini diklasifikasikan kepada orang-orang yang memakai perlengkapan yang branded sebagai produk yang terstandarisasi. Definisi identitas itu sendiri dapat dipandang melalui budaya yang memiliki arti sebagai seseorang yang memiliki suatu hal yang membedakan dirinya dengan orang lain sehingga lebih mudah untuk dikenal.

Sebuah life style atau gaya hidup merupakan sesuatu yang dibentuk, diciptakan, dijiplak kemudian didaur ulang sehingga dapat digunakan dalam kehidupan manusia, terutama masyarakat yang berada di dunia konsumsi dan budaya populer. Untuk dapat mendefinisikan setiap individu, dapat dilihat melalui bagaimana individu tersebut mengonsumsi barang atau jasa. Konsumsi diartikan sebagai suatu penggunaan dari komoditas dalam memenuhi sebuah hasrat untuk menghasilkan kepuasan tersendiri. ${ }^{5}$ Selain itu, life style juga memiliki relasi yang kuat mengenai pemaknaan status sosial ekonomi. Sehingga sebuah gaya hidup menciptakan keberadaan dari orang tersebut dalam dunia global ini.

Awal kemunculan konsumsi itu sendiri terjadi pada tahun 1990-an, tentunya dengan perkembangan dari masyarakat konsumen itu sendiri. Terdapat sebuah ideologi mengenai konsumerisme, yakni berupa sugesti yang memaknai kehidupan manusia yang dilihat dari apa yang dikonsumsi bukan apa yang dihasilkan. Ideologi dari konsumerisme tersebut merupakan suatu bentuk pengalihan dimana setiap masyarakat akan mengalami hasrat dalam berkonsumsi yang tidak ada habisnya. Dengan mengonsumsi komoditi, bagi masyarakat konsumer dapat memberikan suatu identitas sosial. Jika tidak

${ }^{5}$ Herbert Marcuse dalam One Dimensional Man mengemukakan bahwa "kita dapat membedakan kebutuhanyang benar (true) dan kebutuhan yang semu (false). Semu adalah segala hal yang dipaksakan kepada individu oleh kepentingan-kepentingan sosial tertentu dalam penindasannya: kebutuhan yang melanggengkan kerja, agrisivitas, penderitaan dan ketidakadilan. Kebanyakan kebutuhan yang ada untuk membatu orang bersantai, bersenang-senang, menyukai dan membenci apa yang disukai dan dibenci orang lain, masuk dalam kategori kebutuhan semu." (cyberspace and culture:14). 
mengonsumsi suatu barang atau jasa, maka akan merasa ketidakutuhan diri. Sedangkan dengan mengonsumsi barang maupun jasa maka akan memberikan efek yang utuh dan juga kebahagiaan yang dirasakan dalam setiap individu.

Di Indonesia sendiri merupakan sebuah negara yang memiliki masyarakat dengan jumlah konsumsi yang cukup tinggi. Masyarakat Indonesia itu sendiri merupakan masyarakat yang tergolong dalam masyarakat modern sehingga mereka dapat menghabiskan kebanyakan waktu yang mereka miliki di pusat perbelanjaan. Mereka menikmati kehidupan yang mewah dan tergolong rakus dalam mengonsumsi komoditas sebagai alat penunjang life style-nya. Gambaran dari pola konsumsi yang dibahas di atas menunjukkan bahwa mereka cenderung mengonsumsi barang guna untuk mewakili identitas dan gaya hidup semata. ${ }^{6}$

Budaya konsumerisme dianggap sebagai budaya yang harus melekat pada masyarakat seolah-olah untuk memperoleh sebuah identitas maka mereka harus memilih sebuah gaya hidup yang menganut kepada budaya konsumerisme. Sebuah gengsi menjadi panutan utama dalam pola konsumsi sehingga akan menghasilkan konsumerisme. Sehingga gaya hidup yang seperti itu menjadi bagian dari manusia yang tidak dapat dipisahkan dari kehidupannya. $^{?}$

\section{B. Metodologi}

Metodologi yang bersifat ilmiah pada umumnya sangat berhubungan erat dengan pengetahuan yang dimiliki manusia. Jika dilihat dari kacamata filsafat, maka metodologi penelitian sangat berhubungan dengan epistemologi yang dapat dikatakan bahwa metodologi penelitian filsafat merupakan bagian dari epistemologi (filsafat pengetahuan). Berhubungan dengan ilmu filsafat formal,

\footnotetext{
${ }^{6}$ Primada Qurrota Ayun, dkk, Cyberspace and Culture (Yogyakarta: Mata Padi Pressindo, 2014), hlm. 40

${ }^{7}$ Primada Qurrota Ayun, dkk, Cyberspace and Culture (Yogyakarta: Mata Padi Pressindo, 2014), hlm.11-21
} 
maka dalam melakukan metodologi penelitian ada persyaratan yang harus dipenuhi. Persyaratan tersebut adalah dengan mendalami dan menguasai metode-metode filsafat utama yang selalu dipergunakan disepanjang sejarah. Jika ingin menggunakan metode filsafat maka logika harus dikuasai secara matang agar penelitian yang dilakukan bersifat rasional. ${ }^{8}$

Dalam analisis data, penelitian ini menggunaka metode yang bersifat kualitatif mengenai pemikiran dari Herbert Marcuse dalam memandang masyarakat yang konsumtif yang terjadi pada era modern ini. Pemikiran dari Herbert Marcuse akan disajikan secara utuh untuk mencari pokok utama dalam memandang masyarakat pada era modern ini. Adapun unsur-unsur umum yang digunakan dalam penelitian ini adalah, pertama ada unsur deskriptif, yaitu semua data yang telah terkumpul terutama data yang bersumber dari pemikiran Herbert Marcuse akan disajikan secara menyeluruh, sitematis dan akurat, dengan menggunakan metode penelitian yang menyeluruh dari berbagai sumber literatur yang telah diperoleh agar mendapatkan kejelasan mengenai pemahaman tentang masyarakat di era modern ini. Kedua interpretasi, yaitu dengan mendalami pemikiran Herbert Marcuse yang kemudian akan dibahas untuk mengungkap arti untuk mendapatkan kejelasan dari pemahaman dnegan memahami bahasa dan simbol penulisan tokoh tersebut. Ketiga idealisasi, yaitu mengungkap pemikiran Herbert Marcuse yang telah dibahas kedalam sebuah konsep yang ideal dan universal sehingga dapat dibahasakan dengan baik dan jelas. ${ }^{9}$

\section{Hasil Penelitian}

Setelah mengulas sebagian kecil dari pemikiran Herbert Marcuse mengenai masyarakat modern sebelumnya dimana Marcuse menganggap bahwa

\footnotetext{
${ }^{8}$ Anton Bakker dan Achmad Charris Zubair, Metodologi Penelitian Filsafat (Yogyakarta: Kanisius, 1990). Hlm 20

${ }_{9}^{9}$ Anton Bakker dan Achmad Charris Zubair, Metodologi Penelitian Filsafat (Yogyakarta: Kanisius, 1990). Hlm 63
} 
masyarakat modern merupakan masyarakat yang berdimensi satu. Yang dimaksud dengan berdimensi satu yaitu masyarakat di era industri ini telah berkiblat hanya pada satu dimensi saja yaitu kapitalisme. Dimensi satu ini telah menimbulkan banyak pengontrolan baru dengan menggunakan cara yang lembut, bebas, nyaman, dan dibuat rasional sehingga masyarakat yang hidup di era ini tidak bisa melepaskan keterbuaian mereka terhadap sistem yang ditawarkan oleh dimensi ini. Masyarakat modern sangat mudah diidentifikasi. Perangkat teknologi merupakan ciri utama dari masyarakat modern sehingga dapat dikatakan bahwa identitas dari masyarakat modern dapat dilihat dari perangkat teknologinya.

Kehidupan dari masyarakat modern tidak jauh dari teknologi dan kapitalisme. Marcuse berpendapat bahwa teknologi yang saat ini sedang berkembang pesat merupakan bentuk pengontrolan dari sistem kapitalisme ini. Ada 4 dampak yang akan dirasakan oleh masyarakat yang diakibatkan oleh sistem ini. Yang pertama adalah dengan banyaknya bermunculan bentukbentuk dari pengontrolan baru, kedua masyarakat yang memiliki perilaku represif tanpa ampun, ketiga tertutupnya wacana dan kritisisme terhadap sistem politik sehingga membuat masyarakat menerima segala bentuk apapun yang ditawarkan, keempat hilangnya pemikiran kritis dari masyarakat mengenai sistem yang sebenarnya tidak sesuai. Hal seperti inilah yang kemudian dianggap sebagai masyarakat yang mempunyai satu dimensi menurut Herbert Marcuse.

Kebebasan yang ditawarkan oleh budaya konsumerisme ini bukanlah merupakan kebebasan sejati namun hanya sebagai alat untuk mengontrol kehidupan manusia itu sendiri. Konsumsi merupakan awal mulanya budaya konsumerisme ini berkembang. Dengan sistem konsumsi yang sedemikian rupa dapat membuat masyarakat merasakan berbagai macam kebutuhan yang sebenarnya tidak mereka butuhkan. Konsumsi dalam hal ini bersifat aktif dan kolektif dimana konsumsi dapat juga merupakan suatu paksaan yang tidak disadari. Tujuan konsumsi juga saat ini telah berubah, yang pada mulanya 
konsumsi dilakukan guna memenuhi kebutuhan pokok manusia, saat ini konsumsi menjadi suatu hal yang harus dilakukan demi tercapainya hasrat dan ditemukannya identitas diri manusia melalui konsumsi tersebut. Hal ini merupakan sebuah efek yang telah ditimbulkan dari adanya sistem kapitalisme lanjutan ini.

Pada era globalisasi seperti sekarang ini, satu hal yang perlu dibenahi oleh masyarakat modern adalah dengan merubah dan memperkuat mentalitas masyarakat. Konsumerisme yang saat ini merupakan suatu proses yang tidak terelakkan. Masyarakat saat ini tidak mungkin mengabaikan atau bahkan menghentikkan proses tersebut. Namun ada baiknya jika masyarakat mau mencari sisi positif dari konsumerisme ini sehingga hal tersebut dapat memberikan dampak yang baik bagi kehidupan masyarakat. Dampak negatif yang sudah sangat jelas dari sistem konsumerisme ini telah berhasil mempengaruhi berbagai tingkah laku manusia dalam kehidupan sehariharinya. Sehingga sikap yang seharusnya dilakukan adalah dengan menentukan sikap yang kuat dan konsisten dalam menghadapi keganasan dari kemajuan era globalisasi yang semakin bekembang.

\section{Simpulan dan diskusi}

Sehubungan dengan realitas yang kian terkapitalisasi, maka kebutuhan manusia tidak lagi didasarkan pada hal-hal yang bersifat prinsipil, melainkan pada kebutuhan pemuasan hasrat. Hasrat dalam hal ini adalah libido publik yang dimainkan oleh kapitalis agar masrarakat pada gilirannya hanya berdimensi satu sebagaimana disinggung Herbert. Ketika manusia berdimensi satu, artinya manusia telah mengalami pendangkalan makna dan hidup didasarkan pada insting yang diarahkan oleh kapitalisme, baik itu gaya hidup bahkan pada level cara berpikir.

Jalan ke luar dari masalah ini adalah dengan cara memeperdalam kesadaran manusia dan mengembalikan eksistensi manusia sehingga ia tidak 
sekadar menjadi konsumen dari apa yang sedianya telah ada. Di sinilah letak signifikansi Herbert:

- Bahwa manusia berdimensi satu menggiring pada degradasi eksistensialis di tengah homogenitas perilaku terhadap pasar.

- Secara eksistensialis, manusia yang hanya memiliki dimensi satu adalah manusia yang jauh dari kata otentik. Maka siapapun yang memperturut diri pada hasrat konsumerisme pasar sebagaimana disajikan realitas sosial kapitalistik, maka sudah dipastikan ia merupakan manusia yang tidak otentik.

Bila kita tarik analisa Herbert pada ranah-ranah lain-tidak hanya pada ranah modernisme, pasar, dan realitas permukaan yang telah dicengkeram oleh bayang-bayang kapitalisme-seperti mengarahkannya pada dimensi religius, maka gejala pendangkalan juga terjadi. Namun, dalam penelitian ini, penulis membatasi diri untuk menjangkau diskusi itu, sekalipun tidak pernah benar-benar tertutup. Bahwa pada level tertentu, bahkan kehidupan beragama individu telah mengalami pendangkalan, dan mengarah pada homogenitas ritus. Namun tentu saja spekulasi ini perlu diperluas dan dipertajam lagi.[]

\section{Daftar Pustaka}

Marcuse, Herbert. 2016. Manusia Satu Dimensi. Yogyakarta: Narasi.

Marcuse, Herbert. 2018. Eros dan Peradaban. Yogyakarta: Tanda Baca.

Marcuse, Herbert. 1998. Technology, War, and Fascism. London: Routledge.

Storey, John. 2007. Cultural Studies dan Kajian Budaya Pop. Yogyakarta: Jalasutra.

Boer, Kheyene M, dkk. 2014. Cyberspace and Culture.Yogyakarta: Mata Padi Pressido.

Ihza, Yustiman. 2013. Bujuk Rayu Konsumerisme. Depok: Linea Pustaka.

Sukma, Oman. 2005. Sosiologi dan Politik Ekonomi. Malang: UMM Press

Piliang, Yasraf A. 2003. Hipersemiotika Tafsir Cultural Studies atas Matinya Makna. Yogyakarta: Jalasutra. 
Chaney, David. 1996. Lifestyles; Sebuah Pengantar Komprehensif. Yogyakarta: Jalasuttra.

Lury, Celia. 1998. Budaya Konsumen. Jakarta: Yayasan Obor Indonesia.

Featherstone, Mike. 2005. Posmodernisme dan Budaya Konsumen. Yogyakarta: Pustaka Pelajar.

Tuner, Bryan. 2008. Teori-teori Sosiologi Modernitas Postmodernisas. Yogyakarta: Pustaka Pelajar.

Sudarminta. J. 1983. Kritik Marcuse Terhadap Masyarakat Industri Modern. Jakarta: PT. Gramedia. Dalam M.

Sasatrapratedja (ed), Manusia Multi Dimensional.

Strinati, Dominic. 2010. Popular Culture:Pengantar Menuju Budaya Popular. Yogyakarta: Ar-Ruzz Media

Simamora, Bilson. 2008. Panduan Riset Perilaku Konsumen. Jakarta: Gramedia Pustaka Utama

Setiadi, Nugroho J. 2008. Perilaku Konsumen: Konsep dan Implikasi untuk Strategi dan Penelitian Pemasaran. Jakarta: Kencana

Baudrillard, Jean. 2005. Masyarakat Konsumsi, terj. Wahyunto. Yogyakarta: L Kreasi Waana

Karim, Abdul M. 2009. Sejarah Pemikiran dan Peradaban Islam, Yogyakarta: Pustaka Book Publisher

Sutrisno, Mudji. 2008. Filsafat Kebudayaan - ihtiar Sebuah Teks, Cet-Pertama Jakarta: Hukan Kabisat

A. Hasyimy. 1975. Sejarah Kebudayaan Islam, Jakarta: Bulan Bintang

Yatim, Badri. 1999. Sejarah Peradaban Islam, Jakarta: PT Raja Grafinda Persada Sinaga, Dannerius. 1988. Sosiologi dan Antropologi. Klantan: PT Intan Pariwara.

Heryanto Januar. Pergeseran Nilai dan Komsumerisme di Tengah Krisis ekonomi di Indonesia. Vol 6. No. 1.

Rohman, Abdur. 2016. Budaya Konsumerisme dan Teori Kebocoran di Kalangan Mahasiswa. Karsa: Jurnal Sosial dan Budaya Keislaman. Vol 24. No. 2.

Imamuddin Yuliadi, Analisis Makro Ekonomi Indonesia Pendekatan ISLM, Jurnal Ekonomi Pembangunan, 8/2 (2001): hal 171

Mugeni. Fetrianna T. 2017. Gaya Hidup Shopaholic Sebagai Bentuk Perubahan Perilaku di Kalangan Sosialita. Skripsi Fakultas Ilmu Sosial dan Politik Universitas Islam Negeri Sunan Gunung Djati Bandung. 
JAQFI: Jurnal Aqidah dan Filsafat Islam, Vol. 5, No. 1, 2020 | h. 121-133 Riana Octaviana p-issn 2541-352x e-issn 2714-9420

Falach. Ghulam. 2018. Konsumerisme Manusia Satu Dimensi Tesis Aqidah dan Filsafat Islam Universitas Islam Negeri Sunan Kalijaga Yogyakarta. 